\title{
neofilolog
}

Czasopismo Polskiego Towarzystwa Neofilologicznego

ISSN 1429-2173, 2019, NR 52/1, 11-14

http://dx.doi.org/10.14746/n.2019.52.1.2

http://poltowneo.org/

\author{
Jane Arnold \\ University of Seville \\ https://orcid.org/0000-0002-9025-309X \\ arnold@us.es
}

\section{THE IMPORTANCE OF AFFECT IN LANGUAGE LEARNING}

\begin{abstract}
As language teachers, we have to pay attention to many things in our work but cognitive aspects of foreign or second language learning cannot provide all the information we need. If we also give attention to the affective domain, this can make our teaching more effective. In this article we will be considering some of the affective factors and exploring how they influence the process of language learning. Special emphasis will be placed on implications for teachers in the classroom.
\end{abstract}

Keywords: emotions, motivation, self-esteem, anxiety, group dynamics, confidence, communication

Słowa kluczowe: emocje, motywacja, poczucie własnej wartości, lęk, dynamika grupy, pewność siebie, komunikacja

Cognitive aspects of the student have always been considered a basic factor in learning but now more and more attention is also given to affective factors. Jensen (1998:71) pointed out that "the affective side of learning is the critical interplay between how we feel, act, and think. There is no separation of mind and emotions; emotions, thinking and learning are all linked". Many studies from the neurosciences that deal with learning show that a positive affective environment puts the brain in the optimal state for learning: low stress and high interest in the learning process. Referring to second language acquisition, Stern (1983:386) affirmed that "the affective component contributes at least as much 
and often more to language learning than the cognitive skills." Today we know that the progress our students make in language learning and the communicative use of the language can be strongly influenced by affective aspects. However, this was also dealt with long ago; Comenius in the 17th century pointed out the significance of the affective domain, and he considered that it was important to activate all the senses in the classroom and promote interaction, creativity and a good relationship between teachers and learners.

Affect deals with many aspects which relate to language learning and teaching, and it includes not only individual factors but also relational aspects. Earl Stevick (1980: 4) summarized what affect in language learning is about when he wrote that "success [in language learning] depends less on materials, techniques and linguistic analyses, and more on what goes on inside and between the people in the classroom". Thus, success depends less on things and more on people. With inside people he is referring to the individual factors such as motivation, self-esteem, anxiety, inhibition, willingness to take risks, tolerance of ambiguity, learning styles, introversion/extraversion, self-efficacy, etc. What goes on between people, the relational aspects, has to do both with cross-cultural processes and with classroom transactions, where a concern with group dynamics is extremely important for successful learning.

Underhill presented a useful model of the evolution of an educator. In the beginning is the person he calls Lecturer, who knows the language, the minimum requirement, but the Lecturer will find that this isn't enough and so will take courses, etc. and then can become what Underhill calls Teacher, who also knows about methods. However, there will still be difficulties in teaching, and so with more formation and more reflection the Teacher can become a Facilitator, who also knows how to "generate a psychological climate conducive to high quality learning (Underhill 1999: 130).

If we reflect on what greater attention to affect would mean for the language classroom, we would no doubt want to find activities which at the same time as they provide useful work with the language also increase motivation, include personal meaning, reduce anxiety, and give students confidence in learning to speak the language. But even more important than our activities might be a new view of what as language teachers we can hope to achieve in the classroom, which would involve a greater concern for the inner processes of both learners and teachers. Underhill (1999: 131) proposes a broader vision and stresses how "new techniques with old attitudes may amount to no change, while new attitudes even with old techniques can lead to significant change".

In language learning there is a strong relationship between competence and confidence. "Developing greater competence leads to more confidence but also having confidence makes it easier to acquire greater competence", though 
we also need to be aware that "it is not a question of merely telling students 'you can do it!'. Quite the contrary, work with self-esteem and other affective issues is done to provide a supportive atmosphere in which we can better encourage learners to work hard to reach their learning potential" (Arnold 2011: 16).

A significant influence on the learning process comes from the views learners have of their capacity to learn. Research done on the concept of Teacher Confirmation in the area of Communication Studies (Ellis 2004) and extended to the context of language learning (León 2005) strongly emphasizes the role of the teacher in fomenting positive learner beliefs, which will lead learners to participate more actively and thus to better learning for them. Teacher confirmation is "the process by which teachers communicate to students that they are valuable, significant individuals" (Ellis 2004: 2). In her study where many foreign language students were interviewed, León (2005) found that for making students feel valued by their teacher, the following teacher behaviours were important: transmit a sense of confidence, make constructive comments, pay attention to students and really listen to them, smile and make eye contact, show interest in students as people.

We can find many indications from our teaching experience as well as from empirical research which show how attention to affect can bring positive changes to the classroom and that the foreign and second language learning and teaching processes will be more effective if they are affective. In this context, it is clear that the focus is also on being as well as on doing. It is not only a question of what we do but who we are. In a similar vein American educator Parker Palmer (1998: 5) stresses that "technique is what teachers use until the real teacher arrives". And the "real teacher" would surely be conscious of the importance of taking into account the affective dimension in teaching in order to have the best results, since as Rodríguez, Plax and Kearney (1996: 297) pointed out, affect "... is by definition, an intrinsic motivator. Positive affect sustains involvement and deepens interest in the subject matter".

In the document of the Common European Framework of Reference for Languages there is a clear reference to affect in language learning. When dealing with the 'Existential competence' (savoir-être), it lists factors which can influence learners' communicative abilities, such as attitudes, motivations, values, beliefs, cognitive styles, personality factors and states that these "greatly affect not only the language users'/learners' roles in communicative acts but also their ability to learn" (Council of Europe 2001:106).

Undoubtedly, a central function of language is communication. Thus, the concept of communicative competence has a strong influence on language learning programs today. In a language classroom communication is both an end and a means, both a goal and an instrument to reach the goal. Engaging in 
communication requires active participation on the part of learners and this can be strongly influenced by the affective environment in which communication occurs. In their study related to descriptors of mediation in the Common European Framework of Reference, North and Piccardo (2016:23) explain that "Relational mediation is concerned with establishing, maintaining and optimising personal relationships... The user/learner aims to prepare the way for, or refresh, effective communication between participants by promoting a positive relationship with and between them".

Learning a new language can be an adventure for students and their progress can depend to a large extent on the affective dimension of the adventure.

\section{REFERENCES}

Arnold J. (2011), Attention to affect in language learning (in) "Anglistik. International Journal of English Studies", No 22/1, pp. 11-22.

Council of Europe. (2001), Common European Framework of Reference for Languages: Learning, Teaching, Assessment. doi: https://rm.coe.int/16802fc1bf Ellis K. (2004), The impact of perceived teacher confirmation on receiver apprehension, motivation and learning (in) "Communication Education", No 55/1, pp. 1-20.

Jensen E. (1998), Teaching with the brain in mind. Arlington, VA: ASCD.

León I. (2005), La confirmación del profesor de inglés percibida por el alumnado en educación secundaria. Unpublished MA thesis: Universidad de Sevilla, Seville.

North B., Piccardo E. (2016), Developing illustrative descriptors of aspects of mediation for the Common European Framework of Reference (CEFR). A Council of Europe project (in) "Language Teaching”, No 49/3, pp. 455-459.

Palmer P. (1998), The courage to teach. San Francisco: Jossey-Bass Publishers. Stern H. H. (1983), Fundamental concepts of language teaching. Oxford: Oxford University Press.

Stevick E. W. (1980), Language teaching: A way and ways. Rowley, MA: Newbury House.

Rodríguez J., Plax T., Kearney P. (1996), Clarifying the relationship between teacher nonverbal immediacy and student cognitive learning: affective learning as the central causal mediator (in) "Communication Education", No 45, pp. 294-305.

Underhill A. (1999), Facilitation in language teaching (in) Arnold J. (ed.), Affect in Language Learning. Cambridge: Cambridge University Press. 